\title{
Strategi Mengenalkan Matematika Kelas Tinggi kepada Siswa Kelas Rendah Menggunakan Pendekatan Pemecahan Masalah
}

\author{
Rudi Santoso Yohanes \\ Universitas Katolik Widya Mandala Surabaya \\ E-mail: rudisantoso@widyamandala.ac.id
}

\begin{tabular}{l} 
Article Info \\
\hline Article History \\
Received: 2021-10-0 \\
Revised: 2021-11-02 \\
Published: 2021-11- \\
\\
\\
Keywords: \\
Strategy; \\
Mathematics; \\
High grade; \\
Low Class; \\
Solution to problem.
\end{tabular}

\begin{abstract}
Nowadays, in math olympiad classes, there is a tendency to introduce advanced mathematical concepts to lower grade students. Mathematical concepts that are usually taught in high school, are now starting to be introduced in elementary schools, even in lower elementary school grades. Bruner said that introducing mathematics material to children earlier is not a problem as long as the teaching methods used are in accordance with the level of the children' thinking ability. This phenomenon raises challenges for teachers, such as: What are the learning strategies to introduce high level mathematics to low grade students so that advanced mathematics material can be understood meaningfully by them? This research is literature research which analyzes books and other literature related to the problems to be solved. In this article, 4 examples of strategies for introducing high-level mathematics to low-grade students are presented, namely: Distance Speed Time, Linear Equation System, Combinatorics, Area. The results of this study indicate that the problem-solving strategies: guessing and re-testing, making lists, making pictures have great potential to introduce advanced mathematics to low grade students. The advantages of using these problemsolving strategies are: (1) Children do not depend on formulas, (2) Childrens' critical and creative thinking skills, and reasoning can be trained (3) There is possibility for children to find their own formulas.
\end{abstract}

\begin{tabular}{l}
\hline Artikel Info \\
\hline Sejarah Artikel \\
Diterima: 2021-10-09 \\
Direvisi: 2021-11-02 \\
Dipublikasi: 2021-11-22
\end{tabular}

Kata kunci:

Strategi;

Matematika;

Kelas Tinggi;

Kelas Rendah;

Pemecahan Masalah.

\begin{abstract}
Abstrak
Akhir-akhir ini, pada kelas olimpiade matematika, ada kecenderungan untuk mengenalkan konsep matematika kelas tinggi kepada siswa kelas rendah. Konsep matematika yang biasanya diajarkan di sekolah menengah, sekarang mulai dikenalkan di sekolah dasar, bahkan di sekolah dasar kelas rendah. Bruner mengatakan bahwa mengenalkan materi matematika kepada anak lebih awal bukan merupakan masalah, asalkan cara pembelajarannya sesuai dengan taraf kemampuan berpikir anak. Fenomena ini memunculkan tantangan bagi guru, yaitu: Bagaimana strategi pembelajaran untuk mengenalkan matematika kelas tinggi kepada siswa kelas rendah, sehingga materi matematika kelas tinggi dapat dipahami secara bermakna oleh siswa kelas rendah? Penelitian ini merupakan penelitian kepustakaan yang teknik pengumpulan datanya dengan melakukan telaah terhadap buku, literatur yang berkaitan dengan masalah yang ingin dipecahkan. Dalam artikel ini dipaparkan 4 buah contoh strategi mengenalkan metematika tingkat tinggi kepada siswa kelas rendah, yaitu: Jarak Kecepatan Waktu, Sistem Persamaan Linier, Kombinatorik, Luas Daerah. Hasil penelitian ini menunjukkan bahwa strategi pemecahan masalah: menerka dan menguji kembali, membuat daftar, membuat gambar mempunyai potensi yang besar untuk digunakan mengenalkan matematika kelas tinggi kepada siswa kelas rendah. Keuntungan menggunakan strategi pemecahan masalah ini adalah: (1) Anak tidak bergantung pada rumus, (2) Kemampuan berpikir kritis dan kreatif, serta penalaran siswa dapat terlatih, (3) Membuka peluang bagi anak untuk menemukan rumus sendiri.
\end{abstract}

\section{PENDAHULUAN}

Masalah tidak rutin adalah masalah yang jarang atau belum pernah dijumpai oleh siswa. Masalah tidak rutin ini sangat penting untuk dipelajari, karena berhadapan dengan sesuatu yang tidak rutin dan kemudian mencoba menyelesaikannya merupakan ciri khas makhluk hidup yang berakal. Pemecahan masalah (problem solving) merupakan latihan bagi siswa untuk berhadapan dengan sesuatu yang tidak rutin dan kemudian mencoba menyelesaikan. Ini adalah salah satu kompetensi yang harus ditumbuhkan pada diri siswa. Kompetensi seperti ini ditumbuhkan melalui pemecahan masalah. Untuk menyelesaikan masalah yang tidak rutin, siswa harus mengkaitkan konsep 
yang sudah dimiliki yang relevan dengan masalah yang sedang dihadapi. Menyelesaikan masalah tidak rutin, juga sering menggunakan strategi tertentu. Tetapi sayang, strategi dalam menyelesaikan soal-soal yang tidak lazim jarang diajarkan disekolah-sekolah. Hal ini disebabkan karena terbiasanya menyajikan soal-soal matematika yang sifatnya rutin. Dampak pemberian soal seperti ini adalah daya nalar siswa kurang terlatih dan tidak menimbulkan tantangan bagi siswa-siswa yang mempunyai bakat dalam matematika.

Selain untuk meningkatkan prestasi belajar matematika, pemberian masalah tidak rutin juga merupakan sarana untuk melatih siswa menggunakan nalarnya, berpikir kritis dan kreatif serta mengasah intuitif. Dengan demikian pendidikan matematika akan terasa manfaatnya dalam kehidupan sehari-hari karena siswa akan bisa menggunakan kemampuan matematika untuk memecahkan masalah dalam kehidupan sehari-hari. Dengan mempelajari masalah tidak rutin diharapkan siswa semakin menggemari matematika karena mengetahui manfaatnya. Hal ini sejalan dengan dokumen yang dikeluarkan oleh NCTM (2000), bahwa dalam pembelajaran matematika, siswa dituntut memiliki kemampuan memecahkan masalah (problem solving), kemampuan berkomunikasi (communication), kemampuan koneksi (connection), kemampuan bernalar (reasoning) dan kemampuan representasi (representation).

Akhir-akhir ini, di kelas olimpiade matematika, ada kecenderungan untuk mengenalkan konsep matematika kepada siswa lebih awal. Konsep matematika yang dulu diajarkan di sekolah menengah, sekarang mulai dikenalkan di sekolah dasar, bahkan di sekolah dasar kelas rendah, sehingga ruang lingkup materi olimpiade SD dan SMP atau SMP dan SMA tidak ada batas-batas yang jelas. Ada beberapa contoh materi yang dulu dipelajari di SMP sekarang mulai dikenalkan kepada anak SD kelas rendah (kelas 1, 2, 3), yaitu: Jarak Kecepatan Waktu, Sistem Persamaan Linier, Kombinatorik, Geometri. Bruner (Ping Wen, 2018) mengatakan bahwa mengenalkan materi matematika kepada anak lebih awal bukan merupakan masalah, asalkan cara pembelajarannya sesuai dengan taraf kemampuan berpikir anak. Yang tidak diperbolehkan adalah mengajarkan materi matematika kelas tinggi kepada anak kelas rendah dengan menggunakan cara yang digunakan oleh siswa kelas tinggi, Fenomena ini memunculkan masalah baru bagi para guru matematika sekaligus tantangan yang menarik, yaitu: Bagaimana strategi pembelajaran untuk mengenalkan matematika kelas tinggi kepada siswa kelas rendah, sehingga materi matematika kelas tinggi dapat dipahami secara bermakna oleh siswa kelas rendah?

Pembelajaran pemecahan masalah tidak sama dengan pembelajaran soal-soal yang telah diselesaikan (solved problems). Pada pembelajaran pemecahan masalah guru memberikan bekal kepada siswa berbagai teknik penyelesaian untuk menyelesaikan masalah, karena pada dasarnya siswalah yang harus dapat menemukan sendiri, Krulik dan Rudnik (1999) mendefinisikan masalah secara formal sebagai berikut:

"A problem is a situation, quantitatif or otherwise, that confront an individual or group of individual, that requires resolution, and for which the individual sees no apparent or obvious means or path to obtaining a solution."

Definisi di atas menjelaskan bahwa masalah adalah suatu situasi yang dihadapi oleh seseorang atau kelompok yang memerlukan suatu pemecahan tetapi individu atau kelompok tersebut tidak memiliki cara yang langsung dapat menentukan solusinya, Moursund (2005) menyatakan bahwa seseorang dianggap memiliki atau mengalami masalah, bila dia menghadapi empat kondisi berikut ini:

a) Memahami dengan jelas kondisi atau situasi yang sedang terjadi.

b) Memahami dengan tujuan yang diharapkan. Memiliki berbagai tujuan untuk menyelesaikan masalah dan dapat mengarahkan menjadi satu tujuan penyelesaian.

c) Memahami sekumpulan sumber daya yang dapat dimanfaatkan untuk mengatasi situasi yang terjadi sesuai dengan tujuan yang diinginkan.

d) Memiliki kemampuan untuk menggunakan berbagai sumber daya untuk mencapai tujuan.

Dari uraian di atas, dapat disimpulkan bahwa suatu masalah ditandai oleh:

a) Adanya keadaan awal, yaitu informasi tentang situasi tertentu yang dapat dipakai sebagai titik tolak.

b) Adanya keadaan akhir, yang merupakan tujuan.

c) Adanya kesulitan yang secara sadar dialami oleh siswa untuk membawa atau mengubah keadaan awal ke keadaan akhir.

Sehingga dapat dikatakan bahwa seorang siswa dikatakan menghadapi masalah apabila dia 
menyadari menyadari kesulitan untuk membawa atau mengubah keadaan awal ke keadaan akhir. Ini berarti kalau seorang siswa tidak menyadari adanya kesulitan, atau menyadari tetapi tidak berkeinginan untuk mengatasinya, atau seseorang tidak mengalami kesulitan untuk membawa keadaan awal ke keadaan akhir, maka sesuatu itu bukan merupakan masalah bagi siswa tersebut.

Menurut Polya (dalam Rudi Santoso Yohanes, 2018), dalam memecahkan masalah terdapat empat langkah utama, yaitu: (1) memahami masalah, (2) menyusun rencana pemecahan masalah, (3) melaksanakan rencana, (4) memeriksa kembali atau verifikasi. Empat langkah Polya tersebut, dapat disajikan dalam diagram alir seperti gambar berikut:

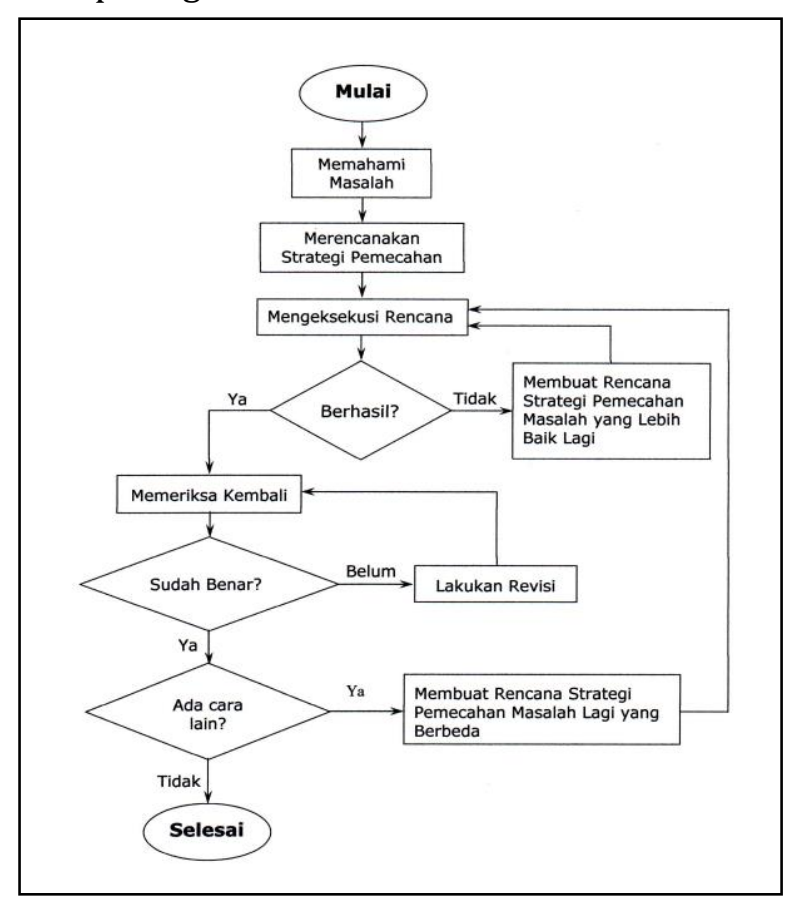

Gambar 1. Alur Pemecahan Masalah Menurut Polya

Terdapat beberapa strategi pemecahan masalah yang dapat membantu siswa SD kelas rendah dalam memecahkan masalah matematika kelas tinggi, antara lain:

a) Menerka dan menguji kembali

Strategi "Menerka dan Menguji Kembali" dapat digunakan dalam banyak permasalahan. Jika banyaknya jawaban yang mungkin itu sedikit, kita dapat menggunakan strategi ini untuk mendapatkan jawaban secara cepat. Dalam kasus lain dimana banyaknya jawaban yang mungkin itu tidak sedikit, kita juga dapat menggunakan strategi ini untuk membuat terkaan dengan menggunakan logika dan menemukan jawabannya. b) Membuat Daftar atau Tabel yang Teroganisir

Membuat daftar/tabel yang terorganisir dapat membantu kita melihat data secara jelas. Daftar/tabel juga dapat membantu kita untuk memastikan bahwa kita benar-benar telah menemukan semua informasi yang relevan. Daftar/tabel juga dapat membantu kita melihat pola di dalam data secara mudah, sehingga kita dapat membuat kesimpulan dengan benar.

c) Membuat Gambar

Membuat gambaran, dan memvisualkan masalah dengan gambar, kita akan memiliki pemahaman yang jelas dari masalah yang sedang kita hadapi, dan akan membantu kita memperoleh ide untuk memecahkan masalah.

d) Melakukan Peragaan

Jika kita dapat membuat peragaan dari situasi yang tergambar dari masalah yang kita hadapi, maka kita akan lebih mudah untuk memahami permasalahan tersebut dan akan lebih mudah untuk memperoleh ide untuk memecahkannya.

e) Bekerja Mundur

Terkadang, akan lebih mudah untuk memulai dengan informasi di akhir masalah dan mengerjakan dari akhir ke awal permasalahan.

f) Menyederhanakan Masalah

Terkadang kita tidak dapat menyelesaikan masalah yang diberikan, tetapi kita dapat menyelesaikan masalah yang memiliki beberapa kemiripan dengan masalah yang kita hadapi. Contoh permasalahan yang lebih sederhana adalah penggunaan angka yang lebih sederhana, sehingga kita akan lebih mudah memahami cara yang dapat digunakan untuk memecahkan masalah yang memiliki kemiripan, sehingga kita dapat menyelesaikan masalah yang diberikan kepada kita (Henry Ong, 2018)

\section{METODE PENELITIAN}

Penelitian ini merupakan penelitian kepustakaan yang teknik pengumpulan datanya dengan melakukan telaah terhadap buku, literatur, serta berbagai laporan yang berkaitan dengan masalah yang ingin dipecahkan. Penelitian ini bertujuan untuk memaparkan strategi yang dapat digunakan untuk mengenalkan matematika kelas tinggi kepada siswa di kelas rendah dengan menggunakan pendekatan pemecahan masalah. Sumber data yang digunakan dalam penelitian ini adalah 
referensi-referensi pustaka yang terkait dengan pemecahan masalah tidak rutin.

\section{HASIL DAN PEMBAHASAN}

Berikut ini disajikan empat buah contoh masalah matematika kelas tinggi yang dapat dikenalkan kepada siswa kelas rendah dan dapat diselesaikan dengan strategi yang sesuai untuk siswa kelas rendah.

A. Strategi Memecahkan Masalah Jarak, Kecepatan dan Waktu

Masalah Jarak, Kecepatan, Waktu dapat dikenalkan kepada siswa kelas rendah dengan strategi membuat daftar/tabel.

\section{Masalah 1:}

Jarak antara dua kota A dan B adalah 650 km. Pada jam 09.00, sebuah truk berangkat dari kota A menuju kota B. Pada waktu yang sama, sebuah mobil berangkat dari kota B menuju kota A. Dalam perjalanan, truk menempuh jarak $60 \mathrm{~km}$ dalam 1 jam, sedangkan mobil menempuh jarak $70 \mathrm{~km}$ dalam 1 jam. Pada pukul berapa mobil dan truk berpapasan? (SEAMO 2019, Paper A)

Jawab:

Masalah di atas, akan diselesaikan dengan strategi membuat daftar/tabel yang menggambarkan jarak yang telah ditempuh oleh truk dan mobil.

Tabel 1. Jarak yang Telah Ditempuh oleh Truk dan Mobil

\begin{tabular}{cccc}
\hline $\begin{array}{c}\text { Waktu } \\
\text { Pukul }\end{array}$ & $\begin{array}{c}\text { Jarak yang } \\
\text { ditempuh } \\
\text { Truk }\end{array}$ & $\begin{array}{c}\text { Jarak yang } \\
\text { Ditempuh } \\
\text { Mobil }\end{array}$ & $\begin{array}{c}\text { Jarak } \\
\text { Truk dan } \\
\text { Mobil }\end{array}$ \\
\hline 09.00 & $0 \mathrm{Km}$ & $0 \mathrm{Km}$ & $650 \mathrm{Km}$ \\
\hline 10.00 & $60 \mathrm{Km}$ & $70 \mathrm{Km}$ & $520 \mathrm{Km}$ \\
\hline 11.00 & $120 \mathrm{Km}$ & $140 \mathrm{Km}$ & $390 \mathrm{Km}$ \\
\hline 12.00 & $180 \mathrm{Km}$ & $210 \mathrm{Km}$ & $260 \mathrm{Km}$ \\
\hline 13.00 & $240 \mathrm{Km}$ & $280 \mathrm{Km}$ & $130 \mathrm{Km}$ \\
\hline 14.00 & $300 \mathrm{Km}$ & $350 \mathrm{Km}$ & $0 \mathrm{Km}$ \\
\hline
\end{tabular}

Jadi, Truk dan Mobil berpapasan pada pukul 14.00 .

B. Strategi Memecahkan Masalah Sistem Persamaan Linier

Masalah Sistem Persamaam Linier dapat dikenalkan kepada siswa kelas rendah dengan strategi Menerka dan Menguji Kembali.

Masalah 2:

Seorang petani memiliki 76 ayam dan bebek. Banyaknya ayam 60 ekor lebih banyak dari bebek. Jika petani tersebut ingin banyaknya ayam dua kali banyaknya bebek, berapa bebek yang harus dia beli? (SEAMO 2019, Paper B)

Jawab:

Akan diselesaikan dengan strategi menerka dan menguji kembali.

Misalkan: Banyaknya Ayam $=\mathrm{A}$

Banyaknya Bebek $=\mathrm{B}$

Syarat yang harus dipenuhi:

$\mathrm{A}+\mathrm{B}=76$

$A=60+B$

Tabel 2. Strategi Menerka dan Menguji Kembali untuk Menentukan banyaknya Ayam dan Bebek

\begin{tabular}{ccccc}
\hline Terkaan & B & $\mathbf{A}=\mathbf{6 0}+\mathbf{B}$ & $\mathbf{A}+\mathbf{B}=\mathbf{7 6}$ & Ket \\
\hline 1 & 6 & $60+6=66$ & $66+6=72$ & TM \\
\hline 2 & 8 & $60+8=68$ & $68+8=76$ & M \\
\hline
\end{tabular}

Jadi,

Banyaknya Ayam $=68$

Banyaknya Bebek $=8$

Jika petani tersebut menginginkan banyaknya ayam dua kali banyaknya bebek, berarti:

Banyaknya bebek $=68 \div 2=34$ bebek.

Jadi, bebek yang harus dibeli petani

$=34-8=26$ bebek

C. Strategi Memecahkan Masalah Kombinatorik

Masalah Kombinatorik dapat dikenalkan kepada siswa kelas rendah dengan menggunakan strategi membuat Daftar/Tabel. Masalah 3:

Terdapat 6 titik yang terletak pada keliling lingkaran. Tentukan banyaknya segitiga yang dapat kamu buat dengan menggunakan titik-titik tersebut. (SEAMO 2018, Paper B)

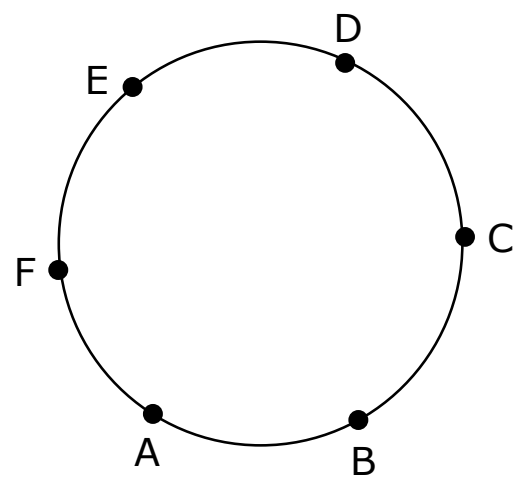

Gambar 2. Kombinatorik dengan 6 titik

Jawab:

Masalah kombinatorik ini diselesaikan dengan strategi membuat daftar/tabel. Semua segitiga 
yang dapat dibentuk secara urut dan sistematis, agar tidak ada yang terlewatkan atau ada yang didaftar ganda.

$\begin{array}{llll}\text { ABC } & \text { BCD } & \text { CDE } & \text { DEF } \\ \text { ABD } & \text { BCE } & \text { CDF } & \\ \text { ABE } & \text { BCF } & \text { CEF } & \\ \text { ABF } & \text { BDE } & & \\ \text { ACD } & \text { BDF } & & \\ \text { ACE } & \text { BEF } & & \\ \text { ACF } & & & \\ \text { ADE } & & & \\ \text { ADF } & & & \\ \text { AEF } & & \end{array}$

Terdapat 20 segitiga.

D. Strategi Memecahkan Masalah Geometri

Masalah geometri dapat dikenalkan kepada siswa kelas rendah dengan menggunakan strategi membuat gambar.

Masalah 4

Perhatikan gambar di bawah ini.ABCD adalah persegi dengan sisi $45 \mathrm{~cm}$. Setiap sisi persegi dibagi menjadi tiga bagian yang sama panjang.Tentukan luas Pesergi panjang EFGH. (SEAMO 2017, Paper B)

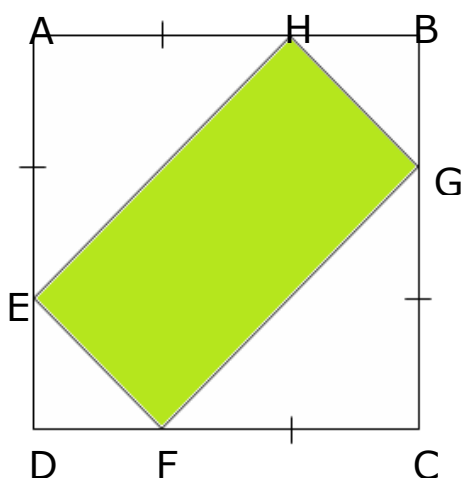

Gambar 3. Kombinatorik 3 Persegi Panjang dengan sisi $45 \mathrm{~cm}$

Jawab:

Akan diselesaikan dengan strategi membuat gambar.

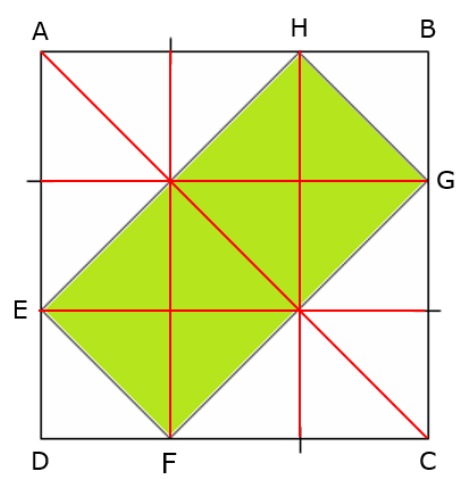

Gambar 3. Kombinatorik 2 dengan sisi $45 \mathrm{~cm}$
Panjang sisi persegi $A B C D=45 \mathrm{~cm}$.

Luas ABCD $=45 \mathrm{~cm} \times 45 \mathrm{~cm}=2025 \mathrm{~cm}^{2}$

Luas $9 \mathrm{pk}=2025 \mathrm{~cm}^{2}$

Luas $1 \mathrm{pk}=\frac{2025}{9} \mathrm{~cm}^{2}=225 \mathrm{~cm}^{2}$

Luas EFGH $=4 \times$ Luas pk.

Luas EFGH $=4 \times 225 \mathrm{~cm}^{2}=900 \mathrm{~cm}^{2}$

Keterangan:

$\mathrm{pk}=$ persegi kecil

Demikian empat buah contoh strategi mengenalkan konsep matematika kelas tinggi kepada siswa kelas rendah. Penggunaan strategi untuk mengenalkan konsep matematika kelas tinggi kepada siswa kelas rendah yang dipaparkan diatas, juga mempunyai beberapa manfaat, yaitu:

1. Anak tidak bergantung pada rumus.

2. Kemampuan berpikir kritis dan kreatif, serta penalaran siswa dapat terlatih.

3. Membuka peluang bagi anak untuk menemukan rumus sendiri.

\section{SIMPULAN DAN SARAN}

A. Simpulan

Berdasarkan pemaparan empat contoh yang telah diuraikan pada hasil penelitian di atas, tampak bahwa konsep matematika kelas tinggi dapat dikenalkan kepada siswa kelas rendah dengan menggunakan strategi yang sesuai dengan cara berpikir siswa kelas rendah. Strategi yang dapat digunakan untuk mengenalkan konsep matematika kelas tinggi kepada siswa kelas rendah yang dipaparkan dalam artikel ini adalah: 1) Strategi membuat daftar, 2) Strategi menerka dan menguji kembali, 3) Strategi membuat gambar. Strategi ini juga mempunyai manfaat sebagai berikut: 1) Anak tidak bergantung pada rumus, 2) Kemampuan berpikir kritis dan kreatif, serta penalaran siswa dapat terlatih, 3) Membuka peluang bagi anak untuk menemukan rumus sendiri.

\section{B. Saran}

Adapun saran yang dapat disampaikan berdasarkan hasil penelitian ini, yaitu: Guru diharapkan semakin tertantang untuk mengeksplorasi strategi yang dapat digunakan untuk mengenalkan konsep matematika kelas tinggi kepada siswa kelas rendah yang sesuai dengan taraf berpikir siswa kelas rendah, sehingga materi 
matematika kelas tinggi dapat dipahami secara bermakna oleh siswa kelas rendah.

\section{DAFTAR RUJUKAN}

Henry Ong. 2018. Singapore and Asian Schools Math Olympiad (SASMO), Singapore: SIMCC

Krulik, S. \& Rudnick, J.A., 1999. Innovative Tasks to Improve Critical and Creative Thinking Skills. Dalam Stiff, L.V. \& Curcio, F.R. (eds). Developing Mathematical Reasoning in Grades K-12. 1999 Year book. p. 138-145. NCTM, Reston, Virginia.

Moursund, D., 2005, Improving Math Education in Elementary School: A Short Book for Teacher. Oregon: University of Oregon. [online]. http://darkwing. uoregon.edu/

NCTM. 2000. Principles and Standards for School Mathematics. Reston, Virginia.

Ping Wen, 2018, Application of Bruner's Learning Theory in Mathematics Studies, International Conference on Contemporary Education, Social Sciences and Ecological Studies (CESSES 2018)
Rudi Santoso Yohanes, 2018, Analisis Kemampuan Berpikir Tingkat Tinggi Mahasiswa Program Studi Pendidikan Matematika, Universitas Katolik Widya Mandala Madiun, Laporan Penelitian, Universitas Katolik Widya Mandala Madiun.

Southeast Asian Mathematical Olympiad (SEAMO) 2017, Paper B (9 - 10 Years)

Southeast Asian Mathematical Olympiad (SEAMO) 2018, Paper B (9 - 10 Years)

Southeast Asian Mathematical Olympiad (SEAMO) 2019, Paper A (7 - 8 Years)

Southeast Asian Mathematical Olympiad (SEAMO) 2019, Paper B (9 - 10 Years) 